\title{
Past Wars in Present Stories: An Analysis of the Picturebook Vanishing Colors
}

\author{
Silje Neraas ${ }^{1}$ (D) \\ Published online: 18 September 2020 \\ (c) The Author(s) 2020
}

\begin{abstract}
In a time when war has forced a vast number of children to flee their homes, flight from war is an important and timely topic explored in a variety of ways in contemporary picturebooks. The Norwegian picturebook Fargene som forsvant (2017) or Vanishing Colors (2019)_addresses the topic through the story of an unnamed girl's experience of having to leave her home. Vanishing Colors does not shield the reader from the terrible harm war does to individuals; it examines the experience of losing one's home and former life. By analysing the picturebook in light of the concept of cultural memory, this article explores Vanishing Colors' use of intertextual and intervisual references to past narratives of war and flight. I examine these references as part of our "collective knowledge" (Assmann 1995, p. 132), which allows the picturebook to recount both the story of an individual and a collective experience of war and flight.
\end{abstract}

Keywords Cultural memory · Intertextuality $\cdot$ Intervisuality $\cdot$ Picturebook $\cdot$ Flight from war $\cdot$ Refugees

\section{Introduction}

This article presents a literary analysis of the Norwegian picturebook Fargene som forsvant (2017)_or Vanishing Colors ${ }^{1}$ (2019)_by Constance Ørbeck-Nilssen and Akin Duzakin, focusing specifically on the experience of war and flight shown against the backdrop of cultural memory. Vanishing Colors has been a topic of

\footnotetext{
1 The picturebook has been translated into American English, and I am using the title of the official translation. However, all quotes from the verbal text in this article are my own translation from Norwegian, the picturebook's original language. The quotes may therefore differ from the American translation.
}

Silje Neraas

silje.neraas@ntnu.no

1 Norwegian University of Science and Technology (NTNU), Trondheim, Norway 
discussion in connection with the ongoing refugee situation, particularly in the context of the representation of refugees in literature, as well as the question of how to address the refugee crisis with children (see Lello, 2018, and Lundh, 2018, for two such instances). The picturebook recounts the story of a child who experiences war and is forced to flee from her home, focusing on the events of the last night the unnamed girl and her mother spend in their war-torn city before leaving. While the mother sleeps, the girl speaks with a bird who helps her restore her lost memories of life before the war.

The title Vanishing Colors alludes to the book's use of colours as a metaphor for memory: as the girl recalls her past, the initially achromatic images gradually fill with colour. A picturebook's use of colours conveys emotions and influences the reader's interpretation (Nodelman, 1988). In Vanishing Colors, the colours are closely connected to the girl's gradual recollection of her past, making memory the clear focus of the story. The girl's personal memories are only one aspect of this theme, however. While she is remembering her past in the form of flashbacks, the book weaves in references to armed conflicts like the Syrian civil war, the Bosnian civil war and the Second World War. Vanishing Colors thus establishes a twofold memory structure that it uses to reflect on experiences of war and flight on two levels- the individual and the collective.

Scandinavian research examining picturebooks that address flight from war is scarce. In Sweden, researcher Åsa Warnqvist has thus far made the most substantial contribution. She has twice analysed contemporary picturebooks published in Sweden between 2014 and 2018, focusing on narrative structure in connection with the representation of refugees and the concept of home (Warnqvist, 2016, 2018). Research focusing on war-themed picturebooks has been mostly concerned with the shift from depicting war as an adventure or putting it in the context of nation-building, to critical viewpoints and nuanced contributions to war discourse. Within this framework, the use picturebooks make of intertextual and historical references has been examined (Vold, 2015; Skyggebjerg, 2015; Samoilow, 2019). Intertextuality and historical references have also been of interest to international research (see for instance Kalogirou and Economopoulou, 2013; Kerby, et al., 2019).

In this analysis, I will examine how the contemporary picturebook Vanishing Colors employs references to other narratives of war and flight as a literary means of expression, and will place these references in the framework of cultural memory as defined by Jan Assmann:

The concept of cultural memory comprises that body of reusable texts, images, and rituals specific to each society in each epoch, whose "cultivation" serves to stabilize and convey that society's self-image. Upon such collective knowledge, for the most part (but not exclusively) of the past, each group bases its awareness of unity and particularity. (Assmann, 1995, p. 132).

Vanishing Colors' references will be viewed as reusable texts or images that function as part of a collective knowledge; special attention will be devoted to their origin and how they work together. The references will also be viewed as an act of selective recollection that creates a narrative, consciously or not (Bal, 1999). This 
study's goal is to pinpoint what they convey when gathered in the same picturebook. In other words: what meanings does Vanishing Colors express through the selection and copresence of its references?

To answer this question, I will first analyse the references found in Vanishing Colors. I will discuss these by employing the concepts of intertextuality, intervisuality and palimpsest to document the copresence of different narratives in the text. The well-known concept of intertextuality was first introduced by Mikhail Bakhtin and developed further by Julia Kristeva, Gerard Genette and others (Suero and Cabo, 2014).

Intertextuality is frequently employed in picturebooks, particularly in crossover picturebooks that address a dual audience (Ommundsen, 2018). I will draw on Genette's understanding of intertextuality as two or more texts becoming connected to each other, creating a copresence between texts (1997). For the study of picturebooks, Maria Nikolajeva has introduced the concept of 'intervisuality' (Nikolajeva, 2008, p. 67). While Nikolajeva does not discuss the term in depth, I understand her use of intervisuality to be a parallel to intertextuality, with only the visual aspect distinguishing the two concepts. Because Vanishing Colors does not merely cite other literary and visual works, the terms intertextuality and intervisuality will also encompass references to other cultural expressions that are based on historical events. In this broad definition, the two terms are closely related to the literary device of allusion (see for instance Epstein, 2011).

The concepts of intertextuality and intervisuality help to highlight that the merged references to various narratives of war and flight give Vanishing Colors a palimpsestical character. The term palimpsest is perhaps best known to literary theory through Genette (1997/1982). In its original meaning, the word refers to reused writing material, most often parchment or papyrus. When writing was erased so the material could be reused, the old text sometimes remained partially visible (British Library, 2016). Thus, the term denotes several simultaneously visible layers of text that are not necessarily thematically connected, as the connection is formed in the reader's perception.

My argument is that the copresence of references allows the picturebook to transcend the depiction of an individual's experience of war and flight, placing a personal story within a larger cultural context. The simultaneous presence of an individual and a collective narrative emphasises that the act of remembrance occurs in a sociocultural framework, where memory belongs to both the individual and their cultural context (Erll, 2011a).

\section{Two Civil Wars}

Vanishing Colors connects the individual story of the girl to collective narratives of war and flight from war by means of intertextual and intervisual references as well as its publishing context. As mentioned above, Vanishing Colors has been positioned and understood as a literary work about the contemporary refugee situation. When 
Vanishing Colors was published, the Syrian civil war had recently been omnipresent in Norwegian news media. ${ }^{2}$ The picturebook's images of a destroyed city were thus easily connected to the conflict in Syria, and more specifically the city of Aleppoan association the picturebook supports by showing a city with minarets, suggesting a predominantly Muslim population. Aleppo dominated the media coverage because of its strategic importance in the war, where the mantra has been "where Aleppo goes, Syria goes" (Hellestveit, 2018, p. 28, translation mine). The city is therefore imbued with symbolical significance. When covering the Syrian civil war, Norwegian media focused both on the war's vast destruction and on people forced to flee their homes, with a special emphasis on civilians as the victims of war. The most iconic images that reached the Norwegian public were of children, such as the footage of five-year-old Omran Daqneesh from Aleppo injured in an air strike, or the images of three-year-old Alan Kurdi, who drowned while trying to cross the Mediterranean Sea with his family.

Vanishing Colors also alludes to the Bosnian civil war, the largest armed conflict in Europe after the Second World War. The Bosnian war caused massive destruction and over 100,000 deaths, with a large part of the casualties being civilians, and atrocities like ethnic cleansing shocking the international community (Holm-Hansen, 2018). Like the Syrian civil war, this conflict dominated Norwegian media and was extremely present in public awareness, partly as a consequence of Norway's participation in the UN's peacekeeping forces in Bosnia and Herzegovina (Gustavsen and Tollefsen, 2018). The Bosnian war's impact on the Norwegian public was so strong it even reached popular culture: in 1992, child star Kine Ludvigsen released the song "Sarajevo" as part of Lillehammer Olympic Aid. Vanishing Colors' connection to the Bosnian war is established in the first two spreads through intervisual references to Christian and Islamic symbols, as well as a historical reference to the Stari Most bridge. The destruction of this bridge-which had been a symbol of the peaceful coexistence of different religions and ethnic groups (Petrovic, 2013)—was a deliberate symbolic act in the Bosnian war, and together with images of Sarajevo, the Stari Most became a dominant symbol of the conflict for Norwegians.

An analysis of the picturebook's first two double spreads reveals that Vanishing Colors immediately establishes numerous references to collective narratives of war and flight by using religious symbols. The first double spread (Fig. 1) shows the girl lying in her mother's lap and listening as she whispers to her in the dark; the background depicts destroyed buildings and a broken bridge, a recurring image throughout the book. ${ }^{3}$

The first double spread establishes a reference to Christianity by evoking Christian symbols and images. The visual focus on the mother and girl is enhanced by the image's use of dark and light tones; the buildings in the background are shrouded in darkness, while the mother and girl are framed by the remains of a white wallpaper with a pattern resembling descending birds or the fleur-de-lis-a traditional

\footnotetext{
2 The Syrian war is now no longer a civil war, but a war fought by multiple nations on Syrian soil.

3 All illustrations in this article are reproduced with the permission of the author, the illustrator and the publishing house, Vigmostad \& Bjørke.
} 


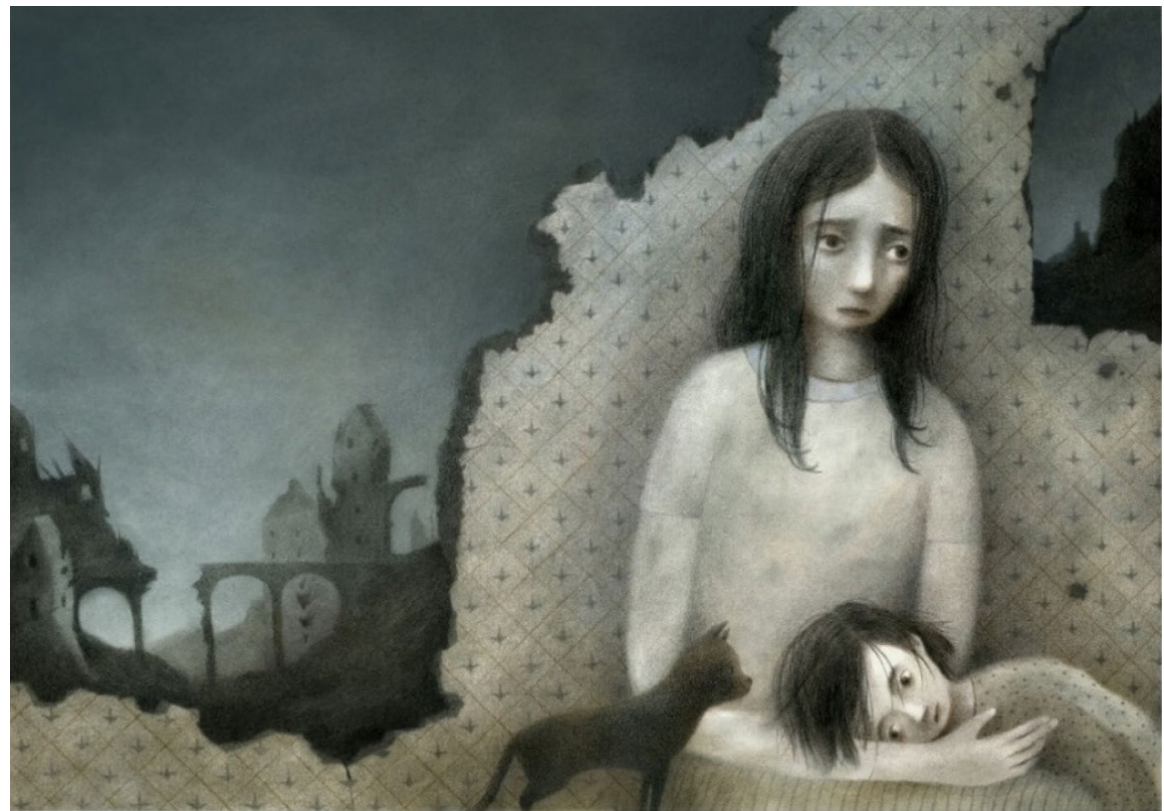

Fig. 1 Mother and daughter sit down for the night (Ørbeck-Nilssen and Duzakin, 2017)

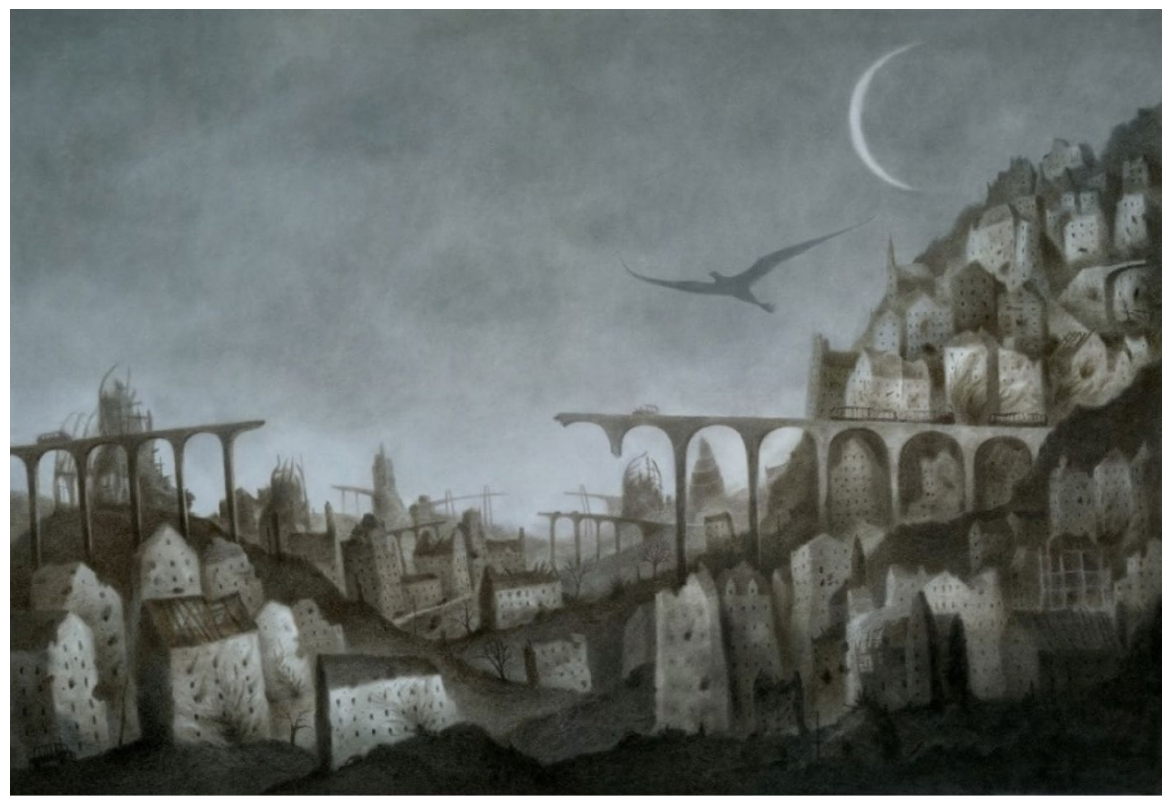

Fig. 2 Cityscape with a bird descending from the mountain (Ørbeck-Nilssen and Duzakin, 2017) 
Christian symbol closely associated with the Virgin Mary. The mother's sorrowful face dominates the image. The characters' pose creates an intervisual reference to the Christian Pietà-motif, which shows the lamenting Virgin Mary with the body of Jesus in her lap. This reference is supported by the wallpaper's fleur-de-lis pattern. In the second double spread (Fig. 2), the reader then encounters a cityscape with the ruins of numerous buildings and bridges. A large bird and crescent moon can be seen in the sky on the right. The ruined buildings could be churches or cathedrals, but this double spread's dominant religious reference is the crescent moon, an Islamic symbol. The verbal text narrates that the mother is telling a story about a benevolent bird that descends from the mountains in the evening to spread protective wings over their house. The presence of the bird in the image takes it out of the mother's story and into the picturebook's reality.

The first two double spreads' merging of Christian and Islamic symbols places the picturebook's geographical setting in a city where the two religions exist side by side. To a Norwegian reader, this evokes the Bosnian war, particularly as the damaged bridges create an intervisual reference to the Stari Most in the city of Mostar. The merging of references to two civil wars in these images shows that Vanishing Colors does not allude to $a$ specific war. Instead, the story of the girl and mother can be read as a mimetic representation of experiences based on two actual wars, which serves as a universal narrative of war and flight that underscores the atrocity of war in general.

\section{The Conference of the Birds}

The role of the bird in Vanishing Colors opens the picturebook to a different way of reading: an allegorical one. As Ørbeck-Nilssen herself pointed out in an interview (Lundh, 2018), the bird is a reference to the epic poem The Conference of the Birds, originally written in 1177 by the Persian poet and mystic Farid ud-Din Attar. Unlike the other fictional and historical narratives Vanishing Colors refers to, The Conference of the Birds is not about war or flight from war, but an allegory about the search for God. The poem recounts the story of a group of birds that set out to find their king, Simurgh. Because the journey is long and hazardous, the birds are initially hesitant about undertaking it, and their numbers dwindle significantly on the way. Only thirty birds survive to reach the Simurgh's abode. There, the birds have to account for their actions during the journey, but are forgiven and receive an important insight: "In the reflection of these thirty birds' faces in the world, they also met Simurgh's face in the world" (Attar ud-Din, 2002/1177, p. 396, translation mine). They realise that they themselves are Simurgh, and Simurgh is them. As Kari Vogt points out in her introduction to the poem, the religious allegory demonstrates the inseparable bond between the birds and their king - and so between human beings and their God (Attar ud-Din, 2002/1177, p. LIV). The birds' realisation does not end their journey, so they continue.

While the reference to The Conference of the Birds is arguably the most obscure one in Vanishing Colors, it is an important presence throughout the book. For instance, both the picturebook and the poem emphasise the process of leaving. The 
girl, like the birds, expresses fear of leaving and of what awaits her and her mother: "But where can we go? Every bridge has collapsed. The roads are ruined. We do not have food or drink" (double spread 13). The endings of the stories are similar, as well: neither the birds nor the girl have reached their destination when the reader leaves them. Instead of closing with a journey's end, the story of Vanishing Colors ends as the journey is about to begin. Also, the poem's narrative is itself a part of Vanishing Colors as an adapted allegory the bird tells the girl:

Listen, the bird whispers.[...] A large flock of birds went on a long and hazardous journey. There were many thousands of them. They had to find a safe place where the entire flock could be. But they could not agree on where to go. Then they decided to ask the eldest bird for advice. Stay together, was all the eldest bird said. (double spread 13-14).

After telling the story, the bird says that the rainbow forms a bridge that reminds us that there is always a way, and that the important thing is to stay together (double spread 15). At the end of the picturebook, an element of hope enters the narrative, underscored by the use of colours: when the bird flies away and dawn breaks, Vanishing Colors presents a parallel to the first spread, where the girl is depicted sleeping in her mother's lap. This time, the mother is looking out over the city not in despair, but with a half-smile. The final spread recalls the second image- the illustration of the city-but now, the city is shown in full colour, with a rainbow above it. The bird's call for staying together is recalled in the picture of the girl and mother with their backs to the reader, looking out over the city, where other people are also gathering.

The bird - who enters the picturebook's world through the mother's story, and thus appears mystical from the start-also plays an active and vital role in restoring the girl's memories. When she meets the bird, the girl cannot see her memories: "All is darkness" (double spread 5). The omniscient bird then narrates the girl's own memories to her: "You are standing in the window and waiting. The air is soon filled with sounds and light. You are wearing your new dress" (double spread 6). Essentially, the bird steps into the role of narrator in order to help the girl recover her past. The first memory the girl recalls is her red dress: "There is something that grows out from the darkness. It was red, I say and smile" (double spread 6). Through the emphasis on restoring the girl's memories of her life before the war, the picturebook addresses the importance of knowing one's own story—one's personal narrative. The bird gives the girl a source of hope for her future; memories and a personal narrative can be a profound source of comfort, and it is one of the bird's functions to highlight the power this kind of narrative holds. Thus, an allegorical reading of the picturebook reveals it to be concerned not merely with fleeing from war, but also with dealing with displacement. 


\section{The Absence and Presence of Colours}

The emergence of memories and the restoration of the girl's personal narrative are accompanied by the gradual colouring of the picturebook's images, making the use of colour central to the story's interpretation. One of Vanishing Colors' most distinctive narrative tools is the contrast between the absence and presence of colours, as well as dark and bright tones. Light and dark "have symbolic and emotional associations for us" (Doonan, 1993, p. 31). They can evoke feelings of well-being and sadness (Ibid.). The achromatic images are also part of what distinguishes Vanishing Colors from other picturebooks. As Perry Nodelman notes, "Color is the norm" (1988, p. 67) when it comes to picturebooks and film. Not using colours can indicate the wish to be taken seriously, as achromatic images evoke documentaries and their claim to objectively revealing the truth (Ibid.). However, Vanishing Colors does not use the lack of colour to denote objectivity. Instead, it deepens the reader's understanding of the girl's mindset by providing symbolic and emotional reinforcement. For instance, the story's achromatic beginning underlines the girl's despair, while the last spread is filled with bright daylight colours and a rainbow, underscoring the hope the girl experiences before leaving her war-torn city. The emotional expressiveness of the picturebook's colours is enhanced by the nature of the girl's memories, which are closely linked to her senses. She remembers by seeing her red dress, hearing the sound of her father's music and smelling the syringa tree where she used to meet her friend.

The way colours are used in Vanishing Colors not only accompanies the recovery of the girl's memories, but also conveys important information in the plotline about her father. The father's absence is not mentioned in the verbal text until the last double spread: "I am thinking about dad. Wondering if I will ever see him again" (double spread 17). He is, however, part of the girl's memories. With its inconclusive account of the father's fate, Vanishing Colors follows a general tendency in picturebooks that address war and flight - they frequently lack resolution when it comes to a parent's fate (Warnqvist, 2018). Vanishing Colors never explicitly states the father's fate, but the picturebook's use of colours is revealing. In the verbal text, the girl remembers disjointed details about her father: his face, smile, wave, or music. In the images, the father's metonymical verbal depiction finds an echo in the girl's last flashback (double spread 11), where everything except him is shown in colour, even the guitar in his hands. The lack of colour might indicate the girl's inability to remember her father because too much time has passed, but could also denote her father's death, and be an expression of the girl's trauma.

The picturebook provides another indication of the father's fate by referencing a historical narrative of war (Fig. 3).

On the left, an image of a man on the side of a building points at the reader with his left index finger. He is wearing what appears to be a Sufi hat, forming a connection to Islam, and his gesture is an intervisual reference to the British First World War recruitment poster "Lord Kitchener wants you!" and the more widely known U.S. version depicting Uncle Sam declaring "I want YOU!". Both of these posters are an appeal made by a nation at war, calling on citizens to do their duty. 


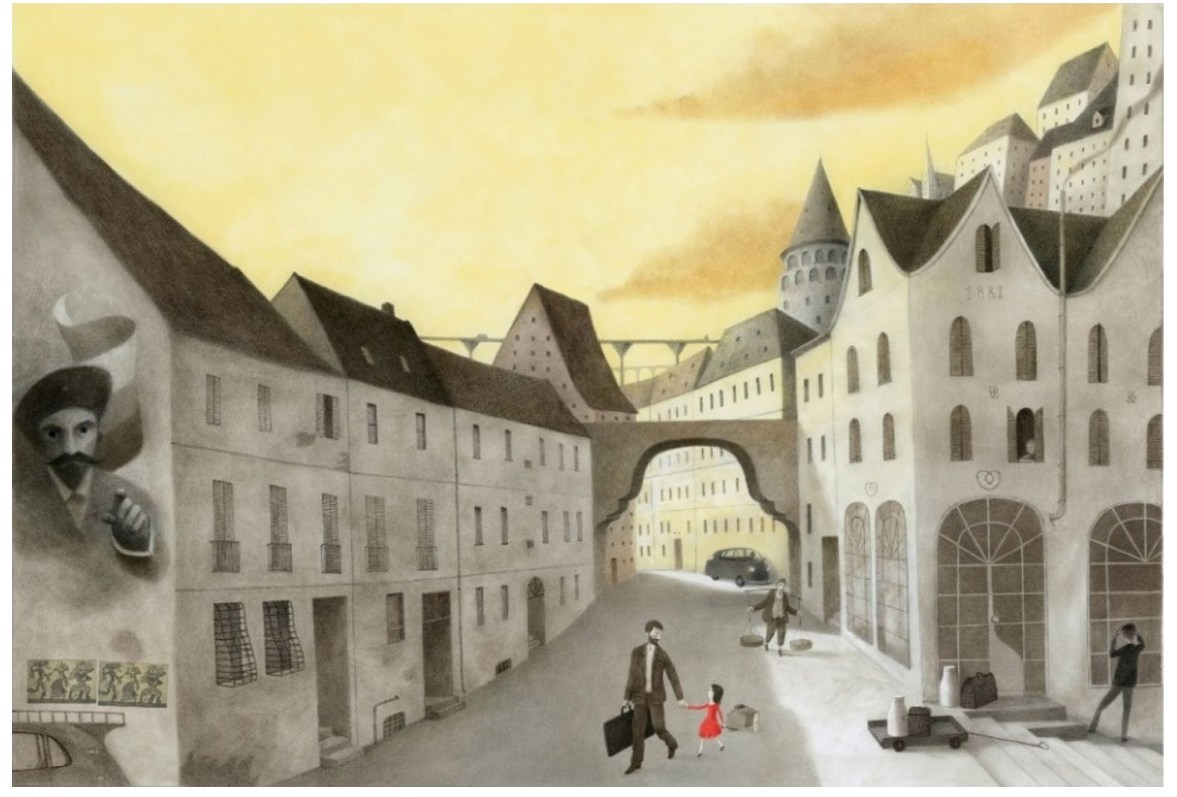

Fig. 3 Father and daughter walking in a street (Ørbeck-Nilssen and Duzakin, 2017)

The image on the wall is the only element of the girl's memory that hints at war, and appears to herald the coming war before it began. It also suggests that the girl's father might have been recruited: when the image on the building is viewed as a recruitment measure, the finger is not pointed at the reader, but at the people passing the poster, including the father. Through the symbolic use of colours and the connection drawn between the father and recruitment posters, he becomes another manifestation of the picturebook's dual memory structure-part of both the girl's individual narrative and the universal and collective experience of war.

The duality of memory as shown by the father is also expressed through the use of colour in the girl's red dress. The girl's recollection of her dress causes the first flashback to her now-missing father and a city untouched by war, and in spreads six and seven, the dress is the clear focal point, its vivid red colour a sharp contrast to the girl's colourless surroundings. The persistent focus on the red dress in both verbal text and image establishes a connection to the red-coated girl in the black-and-white film Schindler's List (Spielberg, 1993), creating a palimpsestical layering of two fictional narratives of war and flight.

The red-coated girl is one of the most iconic images in Schindler's List. She appears in the scene regarded as the film's turning point, where the main character Schindler goes from being a war-time profiteer to saving a group of Jews from the concentration camps (Bal, 2009, p. 19). Schindler's change is triggered when he watches Nazi soldiers destroying a ghetto and sees a little girl with a red coat-the only element of colour in the film-walking alone in the midst of chaos and destruction. In her narratological analysis of the scene, Mieke Bal points out 
that Schindler's change occurs when he sees the individual instead of the "dehumanising bureaucracy of numbers" (Bal, 2009, p. 19). In Vanishing Colors, the main character's red dress suggests the same reading. Like Schindler's List's girl with the red coat, the picturebook's girl is not given a name and can be read as a representation of all children fleeing from war; at the same time, the narrative's use of colour sets her apart and emphasises her individuality.

The palimpsestical layering of the two red-clad girls connects Vanishing Colors with a narrative about the Second World War and the Holocaust, and brings the theme of children and war to the fore. When documenting the Holocaust, images of children are used predominantly - a phenomenon Marianne Hirsch (1999) examines in light of the concept of postmemory. Postmemory has most often been associated with second-generation memories of the Holocaust, but Hirsch generalises it as a "space of remembrance" connected to both personal and public acts of remembrance; to both identification and projection (Hirsch, 1999, p. 9). As she points out, the universality inherent in images of children makes them an ideal vehicle not just for narratives of personal experience, but also collective ones. Interestingly, while the allusion to the girl from Schindler's List refers to a fictional narrative, it creates the same duality that Hirsch finds in the archival images of children, and thus has the same effect.

Vanishing Colors' symbolic use of colour functions on both levels of the story's twofold memory structure. Through its copresence with Schindler's List, the red dress evokes the experience of war and its destruction. The persistent focus on the red dress forms a striking contrast to the achromatic images of the father. The highly saturated colour red is defined as a strong colour, as opposed to the unsaturated colour grey (Doonan, 1993, p. 31). By contrasting the presence and absence of colour, the picturebook presents the theme of life and death, showing that the girl belongs to the former and the father to the latter. The connection between colours and life is also established in the connection of the girl's memories to her senses: she not only remembers her past, but sees it, smells it and hears it. As her personal memory is restored in the bird's presence, her past comes to life for her through her senses. The colours of the girl's memories show that they do not solely consist of war and death, but also of life.

\section{The Selection and Copresence of References}

The origins and nature of the references in Vanishing Colors are very differentthey refer to religious symbols and texts, historical events and a Hollywood film. In the picturebook, however, they are merged, leading to the question posed in the introduction: what meaning does the selection and copresence of the picturebook's references express? There are two underlying assertions in the question that need to be addressed, namely that a meaningful selection of references has been made, and that these references are copresent in the picturebook.

To verify that a selection of references was made, I draw on the concepts 'narrative' and 'cultural memory'. Narrative is the basis of literature. Every fictional story consists of a narrative: a series of events arranged into an organised form. Stories are 
created in a similar way in real life, where we shape, structure and arrange the incidental elements that surround us into a coherent narrative (Nünning and Nünning, 2010 , p. 12). It is narrative that allows us to make sense of the incomprehensible events that surround us ( $\mathrm{Bal}, 2012$, p. 10). However, the shaping and structuring of our real-life experiences is not neutral, but contingent on culture and history; narrative is created by means of selection, deselection and choosing a point of view (Nünning and Nünning, 2010, p. 6). In this way, the creation of narrative forms a parallel to cultural memory as Bal understands it-as an act of selective recollection (1999, p. vii). What is included in a memory depends both on what is and what is not chosen to be part of it, and in cultural memory, "every conscious remembering of past events and experience-individual or collective-is accompanied by strategies which are also fundamental for literary narrative" (Erll, 2011a, p. 146). What is recalled of the past allows us to draw conclusions about the present's need for certain memories (Erll, 2011a, p. 8). Therefore, the selection of references in Vanishing Colors is meaningful, and allows us to gain insight into the contemporary demands that our cultural memory serves.

The reference to the Bosnian civil war is established by means of visual symbols related to religion and historical events. By alluding to this conflict, Vanishing Colors evokes the worst atrocities of war-such as genocide and vast destruction-integrating them into the reader's perception of the story. The references to the recruitment poster and the red dress amplify the sense of the horrors of war and highlight the commonality of such occurrences in wars throughout history. As a reference to a fictional narrative about the Second World War and the Holocaust, the red dress stands out-but how does the fact that the reference cites a fictional story influence reader perception? One possible answer is that when activating the reference, the reader does not ignore its fictionality, but nevertheless acknowledges it as an accepted part of a shared cultural narrative. This "downright paradoxical reading practice" as Astrid Erll (2011a, p. 165) terms it, requires the narrative to be in accordance with an existing understanding on the reader's part: the "memory culture's horizons of meaning" that concern the Second World War and the Holocaust (Erll, 2011a, p. 165). The reference to Schindler's List in Vanishing Colors thus views the film as part of our collective knowledge, which we perceive as converging with non-fictional narratives of the Second World War and the Holocaust.

When considering the picturebook's choice of references as part of its creation of a narrative of war, the reference to The Conference of the Birds is interesting. As has been shown, the allegorical poem is a way to offer hope in the depiction of war and flight from war. But the reference itself also provides some interesting notions within the framework of cultural memory. First, the use of a reference to a Sufi poem indicates a global perspective on cultural memory; shared cultural memory does not necessarily exist only within a single nation and that nation's frame of reference, but can span great geographical distances and reach a multitude of readers. The picturebook thus rises above the "nation-state as a social framework of remembrance" (Erll, 2011b, p. 7). Second, the reference is recounted as an adapted story in Vanishing Colors, meaning that the initial reference does not have to be detected by the reader in order for the message to remain intact (if somewhat simplified through adaptation). This suggests an understanding of the role of literature that includes 
cultivating cultural memory and establishing new or forgotten content—such as the Sufi poem.

The religious intervisual and intertextual references to the Bosnian war and The Conference of the Birds allow Vanishing Colors to be read on an allegorical as well as a mimetical level. This simultaneous availability of different modes of literary discourse echoes a tendency also present in other contemporary picturebooks, where the complexity of the iconotext can simultaneously support both modes (cf. Kalogirou and Economopoulou, 2013, p. 147). The reference to The Conference of the Birds creates a measure of distance to the atrocities of war, but supports the double memory structure like the other references, particularly as the allegorical reading carries the inherent expectation of the all being expressed in the one.

The second assertion contends that by appearing in the same picturebook, the references form a copresence between fictional and factual narratives of war and flight from various times and places, thus establishing a link between narratives that do not necessarily have an intrinsic connection. These references are an important part of the picturebook's literary means of expression, and can be viewed through the lenses of intertextuality, intervisuality and palimpsest. As mentioned in the introduction, I draw on Genette's understanding of intertextuality. Genette emphasises that it is the recipientthe reader-who detects connections between texts, and who establishes a copresence between texts through the perception of intertextual references (Genette, 1997/1982, p. 1-2). In their more recent explanation of the term, Maria Nikolajeva and Carole Scott also emphasise reader perception by characterising intertextuality as "[bringing] our attention to the existence of other 'realities' outside the given text" (Nikolajeva and Scott, 2006, p. 227, emphasis mine).

Genette's, Nikolajeva's and Scott's inclusion of the reader is important when examining Vanishing Colors' twofold memory structure. Perceiving the picturebook's twofold memory structure depends on the reader's ability to connect the girl's plotline to other narratives of war and flight, and thus place Vanishing Colors within a larger cultural context. Also, the fact that Vanishing Colors is a crossover picturebook read by both children and adults means that the intertextual and intervisual references create different levels of interpretation: a child reader may see the red dress as a reference to Little Red Riding Hood, but miss the connection to Schindler's List, and subsequently the line of references to the colour red denoting vulnerability to harm. To a reader who perceives only one reference, this reference might emphasise the particular and singular, and will likely not be understood as a reused and collective image.

Without the guidance of an adult reader, a child reader is also unlikely to detect the references connected directly to war, such as the one to the Bosnian war. Not detecting them does not make the story incomplete, but does keep the reading of the story focused on the individual plotline, rather than connecting it to the collective one. Furthermore, even if we assume that the references are directed towards the adult part of Vanishing Colors' audience, it cannot be assumed that every adult reader will detect all of them. The references differ widely in origin and nature as well as their level of obscurity-the references to Schindler's List and to The Conference of the Birds are perhaps the most extreme examples of this. They therefore create a division between readers based not only on the readers' age, but also on the extent of the readers' knowledge of collective reused images and texts. 


\section{Conclusion}

Vanishing Colors recounts a story of war and flight by referring to previous narratives of war. Although the cited references are varied in nature and origin, their copresence allows the picturebook's depiction to transcend that of a single conflict and create a universal story of being caught in the destruction of war. Through the girl's process of recovering memory, the palimpsestical tale shows that war is part of both an individual and a collective past. Vanishing Colors utilises the selection and copresence of references as a device to express collective experiences of war and flight, embedding these collective experiences in the individual narrative of an unnamed girl's recovery of her personal memories. The picturebook references collective narratives of war like the Bosnian civil war, the Syrian civil war and the Second World War; because these references are anchored in the girl's story, this allows Vanishing Colors to recount narratives of war and flight both on an individual and a collective level, and underscore the inseparable connection between the individual and the collective.

As a picturebook, Vanishing Colors relies on the visual as an important part of its literary expression. Most of the book's palimpsestical references are established primarily through images. Also, the connection between vision and memory is formed on several levels in the iconotext: the girl's inability to remember her life before the war is shown as an inability to see her past, combined with a lack of colour (double spread 5). As the girl gradually recovers her memory, she gains the ability to see colours in both her past and her present, culminating in her realisation that the feathers of the bird are not, in fact, black, but shimmer in a variety of colours (double spread 15). The girl retains the ability to see the colours that surround her when dawn breaks, and the book ends with the girl and mother looking out over their city before leaving.

Analysing Vanishing Colors through the lens of cultural memory reveals which images circulate in our common cultural knowledge. It allows an examination of which elements of the past surface in stories of the present that seek to understand the experience of being in flight from war. The merging of references in Vanishing Colors creates a sense of association and draws parallels between past and present. For instance, the two referenced civil wars are associated with each other, which can prompt the reader to combine their knowledge and cultural frames of reference of the wars. As another example, the girl in Vanishing Colors is connected to the girl in Schindler's List, and through her, the portrayed narrative of war and flight is linked to the narrative of the Holocaust. The cultural memories activated through Vanishing Colors' references are tied into the storybook's narrative about war and flight from war. Vanishing Colors' repeated emphasis on the relationship between the individual and collective, as well as past and present, makes the picturebook stand out as a complex and nuanced work that explores the experience of being a refugee through its dual memory structure. Not least, Vanishing Colors also conveys the message that the vast numbers and the long history of refugees of war are made up of individuals, each one of whom carries a past containing far more than war and destruction. 
Funding Open Access funding provided by NTNU Norwegian University of Science and Technology (incl St. Olavs Hospital - Trondheim University Hospital). This article is part of an article-based PhD project and is connected to the Department of Teacher Education at the Norwegian University of Science and Technology (NTNU). The project as a whole is connected to the research project Barndom $\mathrm{i}$ krisetider: Litterære representasjoner og implikasjoner (BiK) [Childhood in periods of crisis: Literary Representations and Implications].

\section{Compliance with Ethical Standards}

Conflict of interest All authors declare that they have no conflict of interest.

Open Access This article is licensed under a Creative Commons Attribution 4.0 International License, which permits use, sharing, adaptation, distribution and reproduction in any medium or format, as long as you give appropriate credit to the original author(s) and the source, provide a link to the Creative Commons licence, and indicate if changes were made. The images or other third party material in this article are included in the article's Creative Commons licence, unless indicated otherwise in a credit line to the material. If material is not included in the article's Creative Commons licence and your intended use is not permitted by statutory regulation or exceeds the permitted use, you will need to obtain permission directly from the copyright holder. To view a copy of this licence, visit http://creativecommons.org/licen ses/by/4.0/.

\section{References}

Assmann, Jan and Czaplicka, John. (1995). Collective Memory and Cultural Identity. New German Critique 65, 125-133. Accessed March 15, 2020, from https://www.jstor.org/stable/488538

Attar ud-Din, Farid (2002/1177). Fuglenes forsamling. Trans. Arne Ruste. Trondheim: De norske bokklubbene

Bal, Mieke, Crewe, Jonathan, and Spitzer, Leo. (Ed.). (1999). Acts of Memory - Cultural Recall in the Present. Hanover/London: University Press of New England.

Bal, Mieke. (2009). Narratology: Introduction to the Theory of Narrative: Vol. $3^{\text {rd }}$ ed. University of Toronto Press, Scholarly Publishing Division.

Bal, Mieke. (2012). Travelling Concepts in the Humanities - A Rough Guide. Toronto: University of Toronto Press.

British Library. (2016). Palimpsests: The Art of Medieval Recycling. Accessed March 15, 2020 from https://blogs.bl.uk/digitisedmanuscripts/2016/09/palimpsests-the-art-of-medieval-recycling.html

Doonan, Jane. (1993). Looking at Pictures in Picture Books. UK: The Thimble Press.

Epstein, B.J. (2011). "Life is Just an Allusion: The Employment and Translation of Intertextuality in Children's Literature". In Lance Weldy (Ed.) Crossing Textual Boundaries in International Children's Literature, pp. 2-24. UK: Cambridge Scholars Publishing.

Erll, Astrid. (2011a). Memory in Culture. Trans. Sara B. Young. Hampshire: Palgrave Macmillan.

Erll, Astrid. (2011b) Travelling Memory, Parallax, 17:4, 4-18, https://doi.org/10.1080/13534 645.2011.605570

Genette, Gérard. (1997/1982). Palimpsests - Literature in the Second Degree. Trans. Channa Newman and Claude Doubinsky. USA: University of Nebraska Press.

Gustavsen, Marthinussen Elin and Tollefsen, Forø Andreas. (2018). What Became of the Norwegian Peacekeeping Forces? Accessed March 15, 2020 from https://blogs.prio.org/2018/08/what-becam e-of-the-norwegian-peacekeeping-forces/

Hellestveit, Cecilie. (2018). Syria - en stor krig i en liten verden. Falun: Pax Forlag.

Holm-Hansen, Jørn. (2018, 29. desember). Bosnia-krigen. In: Store norske leksikon. Accessed March 15, 2020 from https://snl.no/Bosnia-krigen.

Kalogirou, Tzina and Economopoulou, Vasso. (2013). Questioning Identities Through War: Representations of Victimized Children in Contemporary Picturebooks for Young Readers. In Åse Marie Ommundsen (Ed.), Looking out and Looking in: National Identity in Picturebooks of the New Millennium (pp. 147-164). Oslo: Novus Press. 
Kerby, Martin Charles, Bagueley, Margaret Mary and MacDonald, Abbey. (2019). And the Band Played Waltzing Matilda: Australian Picture Books (1999-2016) and the First World War. Children's Literature in Education, 50(2), 91-109. https://doi.org/10.1007/s10583-017-9337-3.

Lello, Niklas. (2018). Fortellinger om flukt-en samtale med tre forfattere. Accessed January 30, 2020 from https://barnebokinstituttet.no/aktuelt/fortellinger-om-flukt-en-samtale-med-tre-forfattere/.

Lundh, Live. (2018, January 3). Finner håp i vanskelige samtaler. Vårt Land. Accessed January 30, 2020 from https://www.vl.no/kultur/finner-hap-i-vanskelige-samtaler-1.1078796?paywall=true.

Nikolajeva, Maria and Scott, Carole. (2006). How Picturebooks Work. New York/Great Britain: Routledge.

Nikolajeva, Maria. (2008). Play and playfulness in postmodern picturebooks. In Postmodern Picturebooks: Play, Parody, and Self-Referentiality (pp. 55-74). Routledge Taylor \& Francis Group.

Nodelman, Perry. (1988). Words About Pictures: The Narrative Art of Children's Picture Books. Athens: University of Georgia Press. https://search.ebscohost.com/login.aspx?direct $=$ true $\& \mathrm{db}=\mathrm{e} 000 \mathrm{x}$ ww\&AN=621018\&site $=$ ehost-live.

Nünning, Ansgar and Nünning, Vera. (2010). Ways of Worldmaking as a Model for the Study of Culture: Theoretical Frameworks, Epistomological Underpinnings, New Horizons. In Ansgar Nünning, Vera Nünning and Birgit Neuman (Ed.), Cultural Ways of Worldmaking. Concepts for the Study of Culture (pp. 1-25). Berlin/New York: Walter de Gruyter.

Ommundsen, Åse Marie. (2018). Picturebooks for Adults. In Kümmerling-Meibauer, Bettina (Ed.). The Routledge Companion to Picturebooks (pp. 220-231). London/New York: Routledge Taylor \& Francis Group.

Petrovic, Jadranka. (2013). The old bridge of Mostar and increasing respect for cultural property in armed conflict. International Humanitarian Law Series, 40, 1-372. Accessed March 15, 2020 from https:// search.ebscohost.com/login.aspx?direct $=$ true $\& \mathrm{db}=\mathrm{e} 000 \mathrm{xww} \& \mathrm{AN}=503895 \&$ site=ehost-live

Samoilow, Kielland Tatjana. (2019). Konsentrasjonsleir som metafor i skandinaviske bildebøker. Barnelitterart forskningstidsskrift. 10(1). pp. 1-17. https://doi.org/10.18261/issn.2000-7493-2019-01-09.

Skyggebjerg, Karlskov Anna. (2015). Historieformidling og fiction: Contradictio in adjecto. In: Lande, Anne Kristin \& Arneberg, Sofie (Ed.). (2015). På flukt, på vent, på eventyr?: Om krig i barne- og ungdomslitteratur: Kari Skjønsberg-dagene 2015 (Vol. 2-2015, Bibliotheca Nova). Oslo: Nasjonalbiblioteket. pp. 6-19.

Spielberg, Steven (Director). (1993). Schindler's List. Hollywood, CA: Universal Studios.

Suero, Lobato María José and Cabo, Hoster Beatriz. (2014). An Approximation to Intertextuality in Picturebooks. In Bettina Kümmerling-Meibauer (Ed.), Picturebooks - Representations and Narration (pp. 165-183). New York/London: Routledge.

Vold, Tonje. (2015). I krig, på flukt, på eventyr? Norske samtidsbildebøker. In Lande, Anne Kristin \& Arneberg, Sofie (Ed.). (2015). På flukt, på vent, på eventyr?: Om krig i barne- og ungdomslitteratur: Kari Skjønsberg-dagene 2015 (Vol. 2-2015, Bibliotheca Nova). Oslo: Nasjonalbiblioteket. pp. 20-37.

Warnqvist, Åsa. (2016). "JAG FICK EN NY NALLE. JAG FICK ETT NYTT LAND.” Skildringar av flykt från krig i svenska bilderböcker 2014-2016. Tidsskrift for litteraturvetenskap, 46(3-4), 51-66. Accessed February 2, 2020 from https://www.diva-portal.org/smash/get/diva2:1090032/FULLT EXT01.pdf.

Warnqvist, Asa (2018). Family First in Homes Away from Home: Depictions of Refugee Experiences and Flight from War in Picturebooks Published in Sweden 2014-2018. Bookbird: A Journal of International Children's Literature 56(4), pp. 60-71. https://doi.org/10.1353/bkb.2018.0067.

Ørbeck-Nilssen, Constance and Duzakin, Akin. (2017). Fargene som forsvant. Bergen: Vigmostad og Bjørke.

Publisher's Note Springer Nature remains neutral with regard to jurisdictional claims in published maps and institutional affiliations.

Silje Neraas is a PhD candidate at Norwegian University of Science and Technology (NTNU). Her research interest is in children's literature and culture. 